\title{
Consecutive 2-year data analysis to assess the soil quality and ecological risk of heavy metals in Tobacco field: a case study in Northern Bangladesh
}

\author{
Md. Tareq Bin Salam ${ }^{1}$ (1) . S. M. Shahriar Zaman ${ }^{1}$. S. M. Tanzim Hossen ${ }^{1}$. Md. Asaduzzaman Nur ${ }^{1}$
}

Received: 24 October 2020 / Accepted: 4 January 2021 / Published online: 25 January 2021

(c) The Author(s) 2021 OPEN

\begin{abstract}
A successive 2-year (2019 and 2020) field experiment was conducted in northern Bangladesh (Rangpur district) to observe the status of soil quality and heavy metal risk due to tobacco cultivation in this area. Soil samples were collected randomly from four major sub-districts (Rangpur Sadar, Badargonj, Gangachara, and Mithapukur Upazila) where Mithapukur was a non-cultivating tobacco field and the rests were tobacco-growing fields. Along with heavy metal concentrations, physicochemical parameters were analyzed to observe the progressive change in the soil. Results depicted that values of bulk density, particle density, porosity, soil organic matter (SOM), and major nutrients (N, P, K, S) were decreased in the tobacco-growing field from 2019 to 2020, whereas significant improvement was observed in non-tobacco-growing field at successive year analysis. However, exchangeable bases were raised in the tobacco cultivated field from 40.86 to $52.98 \%$ compared to the non-tobacco cultivated field which was in a declining trend (43.66-34.33\%). Overall, the soil pollution index depicted that $\mathrm{Pb}$ was shown a moderate risk of contamination in 2020. The ecological risk analysis also stated that the tobacco field in Rangpur Sadar was at a moderate risk of soil pollution $(R I=126.16)$, although the nontobacco field in Mithapukur was at no risk of pollution $(R I=45.23)$. So, it can be recommended that tobacco cultivation harms the soil health, and thus, it should be prohibited from the agricultural field.
\end{abstract}

Keywords Physicochemical parameters · Heavy metals · Ecological risk index

\section{Introduction}

The plant tobacco is cultivated natively in North and South America. The scientific name of the tobacco plant is Nicotiana tabacum or less widely used Nicotianna rustica [1]. During the "1980s" and "1990s", the tobacco industry started trading heavily in out of the USA specifically Asia's developing countries. Since the mid-1960s of the last century, tobacco has been introduced into the Bangladeshi fields where food crops were grown. It elongated more widely after liberation in 1971 by the British American Tobacco Company in Teesta silt in the Rangpur area [2]. Rangpur is a district that is situated in the northern part of the country. Agricultural soils of Rangpur are very fertile and rice-based. According to the Bangladesh Agricultural Research Council (BARC) [3], here major cropping patterns are Potato/Wheat-T.Aus (HYV)-T.Aman (HYV), WheatJute-T.Aman (HYV), Boro-Fallow-T.Aman. Most renowned rice varieties are grown in boro season where tobacco is being cultivated by replacing boro seasonal rice. Bangladesh is one of the greatest tobaccos uptaking countries in the world. Totally, $0.5 \%$ of people are directly related to tobacco cultivation to their employment. Tobacco is grown throughout the country, with the largest tobacco cultivating areas including Rangpur, Kushtia, and Chattogram Hill [4]. The total cropped area in the Rangpur region is 696,420 ha, whereas 14,221 ha lands are now being tobacco cultivated [3]. Traditionally, the area is one

Md. Tareq Bin Salam, tareqss@swe.ku.ac.bd | 'TSoil, Water and Environment Discipline, Khulna University, Khulna-9208, Bangladesh. 
of the most tobacco-growing areas in the country that is why the Rangpur district was chosen as the study area. Tobacco is an alien species in this area, and this non-local species adversely impacts on the habitats and bioregions environmentally or ecologically. They crumble up an agroecological system by forcing over other cultivated and uncultivated crops essential for the life and livelihood of a community [5]. Tobacco cultivation greatly influences the environment, such as deforestation, environmental pollution due to the utilization of agrochemicals and soil fertility inanition. Tobacco plants take soil nutrients more heavily and consume soil nutrients very fast compared to other crops, thereby making such soils unsuitable for healthy plant growth for the following crops [6]. Therefore, tobacco plants require more chemical fertilizers and pesticides thus lead to potential loss of soil health [7]. The excess use of agrochemicals such as insecticides and herbicides is another factor that contributes a lot to the accumulation of heavy metals in the soil [8]. Tobacco farming contributes to large accumulation of heavy metals in soils especially $\mathrm{Pb}$ and $\mathrm{Cd}$ that has a carcinogenic effects on human body [9]. Apart from that, heavy metals in soil harms soil quality. Especially soil microbial community is strongly suppressed due to the destruction of soil enzymatic activities [10]. So, a comparative research was conducted at tobacco-growing fields and seasonal crops growing field (noted as a non-tobacco field) in Rangpur district to assess the impact of tobacco cultivation on soil health as well as analyze the ecological risk of heavy metals based on two successive years soil physicochemical and heavy metals loading data.

\section{Materials and methods}

\subsection{Study area}

The study was carried out at 4 Upazilas (sub-districts) (Mithapukur, Badarganj, Gangachara, and Rangpur Sadar) of the Rangpur district in Bangladesh (Fig. 1). Tobacco cultivation elongated more widely after liberation in 1971 by the British American Tobacco Company in Teesta silt in the Rangpur area [2]. According to the Bangladesh Bureau of Statistics (BBS) [11], in 2017-2018, the tobacoo cultivation area of Rangpur division was 37,142 acres while in the Rangpur district it was 7883 acres. The farmers of this area are being motivated to produce tobacco by the tobacco manufacturing companies and for this reason, Rangpur district was selected as the studied area to assess the soil quality which might play a potential factor in ensuring long-term soil health.

Rangpur district is situated in the north of the country with an indigenous environment that differs from other parts of the country. The Annual temperature of the Rangpur district varies from " $51^{\circ} \mathrm{F}$ " to " $95^{\circ} \mathrm{F}$ " and sometimes temperature rarely gets below " $46^{\circ} \mathrm{F}$ " and above " $102^{\circ} \mathrm{F}$. In Rangpur, almost $80 \%$ precipitation has been received from May to August

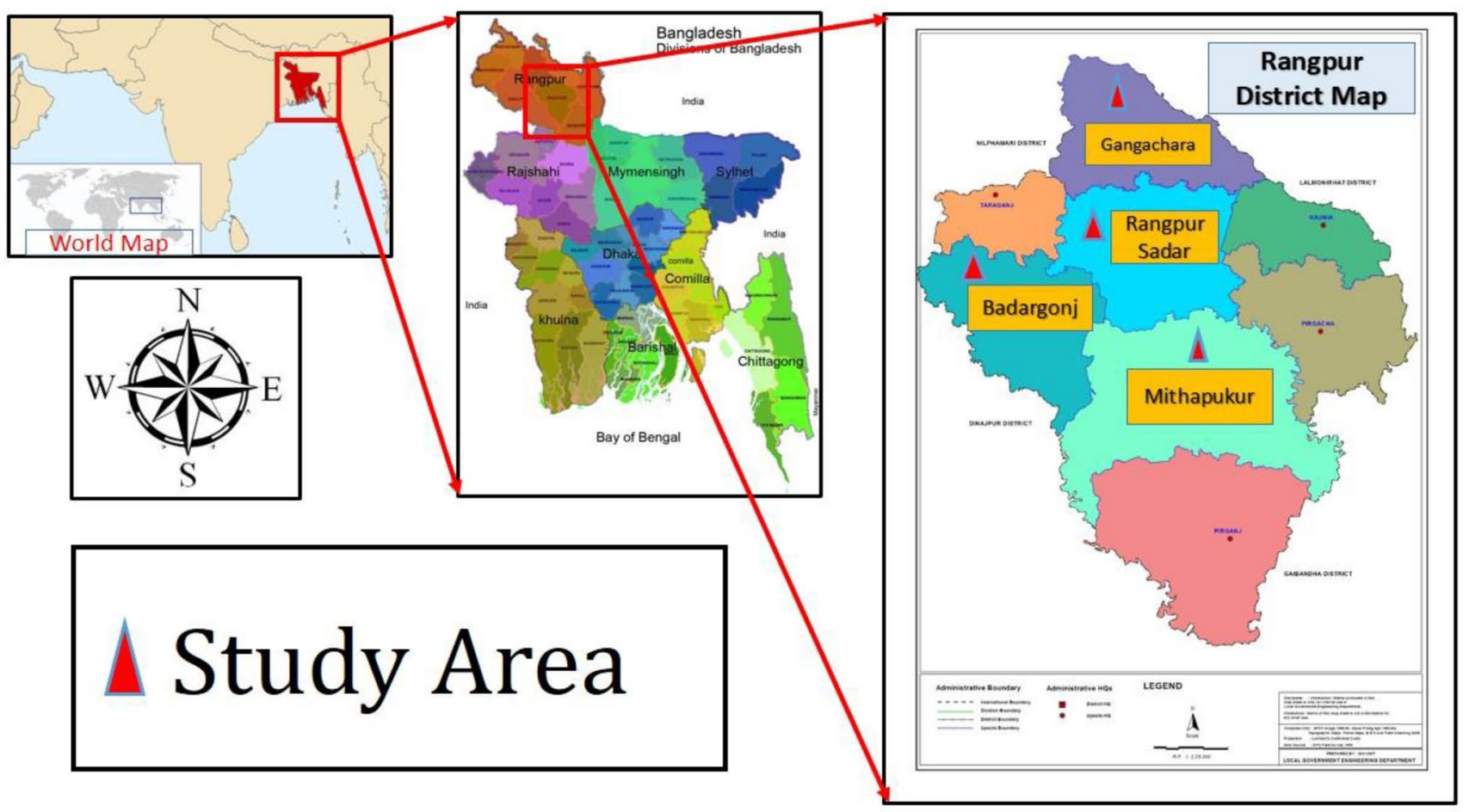

Fig.1 Location of the study area 
and $<20 \%$ precipitation has been received from December to February. In the wet season (March to November), average rainfall occurs about 11.0 inches wherein dry season (November to March), average rainfall occurs about 0.1 inches [12].

During the experiment, loamy textured soil was found in Mithapukur, Gangachara, and Rangpur Sadar, as well as silty loam texture was identified in Badargonj. Mithapukur was chosen as control and designed as a nontobacco field due to not cultivating tobacco in the agricultural soils whereas Badarganj, Gangachara, Rangpur Sadar were designed as the tobacco field due to intensive tobacco cultivation in the agricultural soil. Soil samples were taken in successive years of 2019 and 2020. Locations (GPS) of the study area with site coding are presented in Table 1.

\subsection{Soil sample collection and processing}

Composite soil samples $(0-15 \mathrm{~cm})$ were collected from selected sites for consecutive 2 years in April, 2019, and 2020 respectively. Soil sampling was carried out by composite sampling method as suggested by the Soil Survey Staff of the USDA [13]. All samples were replicated thrice and stored in clean polythene packets, receptively. Then, samples were carried to the laboratory of Soil, Water and Environment discipline, Khulna University, and kept them in the air. After air drying, samples were crushed and sieved by using 2-mm-diameter sieve and finally preserved in plastic containers for further physical and chemical analysis.

\subsection{Analysis of physicochemical properties}

For physical analysis of soil, the bulk density of the soil samples was determined by the core sampling method followed by Blake and Hartge [14]. Porosity (\%) of the samples was determined using Eq. (1) below consists of the value of bulk density (BD) and particle density (PD) [15].

$\%$ Porosity $=\left\{1-\left(\frac{B D}{P D}\right) \times 100\right\}$

For chemical analysis of soil, $\mathrm{pH}$ was measured followed to the glass electrode $\mathrm{pH}$ meter method by calibrated $\mathrm{pH}$ meter (soil/water $=1: 2.5$ by volume) and electrical conductivity was measured by a calibrated conductivity meter [16]. Soil organic matter was determined by Walkley and Black wet oxidation method [17] whereas soil organic matter (SOM) was calculated using organic carbon data [18]. Total nitrogen was determined by the Kjeldahl method [19]. Available phosphorus was analyzed by the Bray-1 extraction method following bluecolorimetry [20]. Available sulfur was determined by the turbidimetric method [21]. Exchangeable potassium $\left(\mathrm{K}^{+}\right)$and sodium $\left(\mathrm{Na}^{+}\right)$were determined by flame photometry [22] while exchangeable magnesium $\left(\mathrm{Mg}^{2+}\right)$ and calcium $\left(\mathrm{Ca}^{2+}\right)$ were determined by atomic absorption spectrophotometer [23]. Cation exchange capacity (CEC) was measured by ammonium acetate $\left(\mathrm{NH}_{4} \mathrm{OAc}\right.$ at $\left.\mathrm{pH} 7.0\right)$ method [24]. BSP, SAR, and ESP were also analyzed. The base saturation percentage (BSP) was determined using Eq. (2). Sodium adsorption ratio (SAR) was determined by using Eq. (3). The exchangeable sodium percentage (ESP) was calculated by using Eq. (4) given below:

$\mathrm{BSP}(\%)=\left\{\frac{\left.\left[\mathrm{Ca}^{2+}\right]+\left[\mathrm{Mg}^{2+}\right]+\left[\mathrm{K}^{+}\right]+\left[\mathrm{Na}^{+}\right] \text {(cmolc/kgsoil }\right)}{\mathrm{CEC}(\mathrm{cmolc} / \mathrm{kgsoil})\}}\right\} \times 100$

$\mathrm{SAR}=\frac{\left[\mathrm{Na}^{+}\right]}{\left\{\sqrt{ }{ }^{1} / 2\left(\left[\mathrm{Ca}^{+}\right]+\left[\mathrm{Mg}^{2+}\right]\right)\right\}}$

$\operatorname{ESP}(\%)=\left(\frac{\left[\mathrm{Na}^{+}\right]}{\mathrm{CEC}}\right) \times 100$

\subsection{Micronutrient and heavy metal analysis}

For the determination of micronutrient ( $\mathrm{Fe}$ and $\mathrm{Zn}$ ) and heavy metals ( $\mathrm{Mn}, \mathrm{Co}, \mathrm{Cr}, \mathrm{Ni}, \mathrm{Pb}$ ), sieved $(2 \mathrm{~mm}$ ) soil samples $(0.5 \mathrm{~g})$ were put into a $100-\mathrm{mL}$ beaker and were digested with nitric-perchloric acid (2:1) as described by Piper [25]. After digestion, digested solutions were diluted to $50 \mathrm{~mL}$ using distilled water and the total $\mathrm{Fe}$, $\mathrm{Zn}, \mathrm{Mn}, \mathrm{Co}, \mathrm{Cr}, \mathrm{Ni}$, and $\mathrm{Pb}$ concentration were analyzed by inductively coupled plasma optical emission spectrometry (ICP-OES) [26].
Table 1 Location (GPS) and site code of the study area

\begin{tabular}{llll}
\hline SL no & Study area & Site code & Location (GPS) \\
\hline 1 & Mithapukur (Non-tobacco Field) & A (NTF) & $89^{\circ} 17^{\prime} 7^{\prime \prime} \mathrm{E}, 25^{\circ} 31^{\prime} 49^{\prime \prime} \mathrm{N}$ \\
2 & Badargonj (Tobacco Field) & B (TF) & $89^{\circ} 4^{\prime} 48^{\prime \prime} \mathrm{E}, 25^{\circ} 43^{\prime} 30^{\prime \prime} \mathrm{N}$ \\
3 & Gangachara (Tobacco Field) & $\mathrm{C}(\mathrm{TF})$ & $89^{\circ} 11^{\prime} 33^{\prime \prime} \mathrm{E}, 25^{\circ} 49^{\prime} 20^{\prime \prime} \mathrm{N}$ \\
4 & Rangpur Sadar (Tobacco Field) & D (TF) & $89^{\circ} 8^{\prime} 21^{\prime \prime} \mathrm{E}, 25^{\circ} 49^{\prime} 8^{\prime \prime} \mathrm{N}$ \\
\hline
\end{tabular}




\subsection{Measurement of soil pollution index (SPI) and ecological risk index (ERI)}

Soil pollution index (SPI), a simple well-known pollution evaluation tool, was applied to identify single element contamination indices. SPI was calculated using the following Eq. (5):

$\mathrm{SPI}=\frac{\mathrm{Ci}}{\mathrm{Cb} i}$

where $\mathrm{SPI}$ is the soil pollution index, $\mathrm{Ci}$ is the concentration of the ith heavy metal in the soil, and $\mathrm{Cbi}$ is its reference level Alloway [27] and WHO [28]. Based on the SPI values, pollution can be classified into five categories: unpolluted $(\mathrm{SPI} \leq 1)$, slightly polluted $(1<\mathrm{SPI} \leq 2)$, mildly polluted $(2<\mathrm{SPI} \leq 3)$, moderately polluted $(3<\mathrm{SPI} \leq 5)$, and highly polluted (SPI $>5$ ) [29].

The ecological risk index (RI) was calculated by using the following formula to assess the ecological risk (ER) of heavy metals [30]:

$\mathrm{RI}=\sum_{i=1}^{n} \mathrm{ER} i$

$\mathrm{ER} i=\operatorname{Ti} \times\left(\frac{\mathrm{Ci}}{\mathrm{Cb} i}\right)$

where ERi is the ecological risk index for the heavy metal $i$, and $T i$ is the toxicity response coefficient for the metal $i$. The toxic response factors for $\mathrm{Mn}, \mathrm{Co}, \mathrm{Cr}, \mathrm{Ni}$, and $\mathrm{Pb}$ are
$10,5,2,6$, and 5, respectively, [31]. Standard grading of potential ecological risk are given in Table 2 [32].

\subsection{Statistical data analysis}

Generated soil sample data were subjected to analysis of variance (One way ANOVA) and Pearson correlation coefficient with computer package software SPSS 16, and general calculations were conducted by using Microsoft Office Excel 13. Data generated from the tobacco cultivated field was compared with the non-tobacco field's data. Group comparison of the means was carried out by Duncan's multiple range test (DMRT) at $95 \%$ confidence level $(p \leq 0.05)$ using SPSS 16.

\section{Results and discussion}

\subsection{Physical parameters}

A comparison of soil physical properties for the successive year's data is presented in Table 3. Results revealed that bulk density was the highest at site $A\left(1.57 \mathrm{gcm}^{-3}\right)$ in 2019 that was decreased in the following year. In other sites, bulk density was slightly increased (average 1.44-1.5 $\mathrm{gcm}^{-3}$ ) from 2019 to 2020. In 2020, among the four different sites, no significant differences were found. In the study of particle density; Site B illustrated the highest value between the years $\left(2.76 \mathrm{gcm}^{-3}\right)$ that was diminished the following year $\left(2.59 \mathrm{gcm}^{-3}\right)$. Except for site $B$, all other sites values were augmented in the following year
Table 2 Classification of potential ecological risk index (Xia et al. 2020)
Table 3 Summary statistics for surface soil physical parameters

\begin{tabular}{llll}
\hline ER value & $\begin{array}{l}\text { Grade of ecological risk of } \\
\text { single metal }\end{array}$ & $\mathrm{Rl}$ value & $\begin{array}{l}\text { Grade of potential eco- } \\
\text { logical risk of the environ- } \\
\text { ment }\end{array}$ \\
\hline $\mathrm{ER}<40$ & Low risk & $\mathrm{Rl}<112.5$ & Low risk \\
$40 \leq \mathrm{ER}<80$ & Moderate risk & $112.5 \leq \mathrm{Rl}<225$ & Moderate risk \\
$80 \leq \mathrm{ER}<160$ & Considerable risk & $225 \leq \mathrm{Rl}<450$ & Considerable risk \\
$160 \leq \mathrm{ER}<320$ & High risk & $\mathrm{Rl}>450$ & Very High risk \\
$\mathrm{ER} \geq 320$ & Very high risk & - & - \\
\hline
\end{tabular}

\begin{tabular}{|c|c|c|c|c|c|c|}
\hline \multirow[t]{2}{*}{ Sites $^{1}$} & \multicolumn{2}{|c|}{ Bulk density $\left(\mathrm{gcm}^{-3}\right)$} & \multicolumn{2}{|c|}{ Particle density $\left(\mathrm{gcm}^{-3}\right)$} & \multicolumn{2}{|l|}{ Porosity (\%) } \\
\hline & 2019 & 2020 & 2019 & 2020 & 2019 & 2020 \\
\hline A (NTF) & $1.57 \pm 0.03 a$ & $1.49 \pm 0.07 a$ & $2.56 \pm 0.10 a$ & $2.59 \pm 0.02 a$ & $38.67 \pm 5.28 b$ & $42.47 \pm 2.55 \mathrm{a}$ \\
\hline $\mathrm{B}(\mathrm{TF})$ & $1.51 \pm 0.01 b$ & $1.55 \pm 0.06 a$ & $2.76 \pm 0.21 a$ & $2.59 \pm 0.14 a$ & $45.29 \pm 3.46 a$ & $40.15 \pm 3.95 b$ \\
\hline$C(T F)$ & $1.39 \pm 0.04 c$ & $1.47 \pm 0.05 a$ & $2.62 \pm 0.16 a$ & $2.66 \pm 0.10 a$ & $46.95 \pm 4.76 a$ & $44.74 \pm 3.32 \mathrm{a}$ \\
\hline $\mathrm{D}(\mathrm{TF})$ & $1.42 \pm 0.04 c$ & $1.49 \pm 0.09 a$ & $2.49 \pm 0.14 a$ & $2.49 \pm 0.07 a$ & $42.97 \pm 5.17 a$ & $40.16 \pm 2.91 b$ \\
\hline
\end{tabular}

${ }^{1}$ Sites:A=Mithapukur, $B=$ Badargonj $C=$ Gangachara, $D=$ Rangpur Sadar (NTF=Non-Tobacco field, $\mathrm{TF}=$ Tobacco field) 
but insignificant. Porosity was higher at site C (46.95\%) in 2019 but declined in the following year (44.74\%). Except for site $A$, the value of all other sites were reduced from 2019 to 2020. In 2020, significant differences were observed between the tobacco and non-tobacco field, and a significant improvement of porosity was observed in the non-tobacco field (38.67-42.47\%). The reduction of porosity in the tobacco fields is a sign of the negative impact of tobacco cultivation which may reduce the soil's waterholding capacity [33]. A similar result was also observed by Moula et al. [34].

\subsection{Analysis of chemical parameters}

The values of different chemical properties are presented in Table 4. pH values were ranged from 6.34 to 6.54 in 2019 and 5.33 to 5.70 in 2020. In 2019, there were no significant differences between the tobacco and non-tobacco fields, but in 2020, tobacco fields showed significantly higher value than non-tobacco fields (Table 4). These decreasing $\mathrm{pH}$ values indicated medium soil acidic conditions thus can be restricted plant growth [33]. Kutub and Falgunee [35] found extremely low $\mathrm{pH}$ under tobacco cultivation than other crops in their study. Still, the study represented a similar trend of $\mathrm{pH}$ change for both tobacco and nontobacco fields.

Table 4 also depicted that EC values were raised for all four sites from 2019 to 2020 that were ranged between $0.98 \mathrm{dS} / \mathrm{m}$ and $1.51 \mathrm{dS} / \mathrm{m}$. In 2019, a significantly higher value was observed in the non-tobacco field than tobacco fields but in 2020, the non-tobacco field presented insignificant results with the tobacco fields. Besides, the value of soil organic matter (SOM) was the best at site B (1.57\%) in 2019 that was reduced to $0.82 \%$ in the following year. It was noted that the SOM value of site $A$ was augmented from 2019 to 2020 (0.81-1.03\%) whereas other sites' values were sharply decreased (average 1.54-0.98\%). In 2020, except site $D$, no significant changes were seen among experimental sites though the non-tobacco field improved the SOM status in successive year data analysis. Moula et al. [34] found a similar SOM change in their study, and he reported that SOM decreased from 1.95 to $1.78 \%$ for consecutive 2 years of tobacco cultivation that supports the study.

\subsection{Major (N, P, K, S) and micro (Fe, Zn) nutrients}

Yearly data of soil major and micronutrient values are presented in Table 5 . The yearly data comparison stated that total $\mathrm{N}$ concentration was slightly upward $(0.11-0.12 \%)$ in 2020 for the non-tobacco field, whereas $\mathrm{N}$ concentrations were dropped off all tobacco cultivated fields. In 2019, all sites showed statistically similar results but in 2020, non-tobacco fields showed significantly best results than tobacco cultivated fields. Table 5 also placed that the concentration of available P was the highest at site B in 2019 that was declined in the following year $(10.5-7.63 \mathrm{mg} / \mathrm{kg})$. Similar findings were also noticed in other sites although the tobacco field's depletion rate was higher. In 2020, the $P$ concentration of the non-tobacco field significantly differed from the tobacco field. However, it was insignificant in 2019 except site D. Results of exchangeable K was placed that $K$ concentration was the finest at site $A$ in 2020 $(0.44 \mathrm{cmolc} / \mathrm{kg})$. A more noticeable fact was that except for site $A, K$ values were lessened sharply from 2019 to 2020 . Site A value was improved from 0.26 to $0.44 \mathrm{cmolc} /$ $\mathrm{kg}$ which indicated the major $\mathrm{K}$ depletion in tobacco cultivated fields. In 2020, the exchangeable $\mathrm{K}$ values of site $A$ was significantly differed from other sites and showed the best result. Available $S$ concentration was also shown downward at all four sites in 2020 compared to 2019 although $\mathrm{S}$ concentration was significantly higher in nontobacco fields $(48.37 \mathrm{mg} / \mathrm{kg})$. Overall, nutrients analysis declared that depletion of major nutrients in tobacco cultivated fields might be caused by the higher nutrient uptake nature of tobacco plants. Yanda [6] found a similar result in his study. He stated that the tobacco plant was a heavy feeder on soil nutrients than other crops and depleted soil nutrients very fast. Oloo [36] also found that tobacco cultivation led to the depletion of soil fertility that is a strong agreement of the research.

In successive year micronutrient data analysis, Fe concentration was higher at site B $(2935 \mathrm{mg} / \mathrm{kg})$ in 2020 . Yearly data depicted that Fe concentration was improved
Table 4 Soil chemical parameters

\begin{tabular}{|c|c|c|c|c|c|c|}
\hline \multirow[t]{2}{*}{ Sites $^{1}$} & \multicolumn{2}{|l|}{$\mathrm{pH}$} & \multicolumn{2}{|l|}{$\mathrm{EC}(\mathrm{dS} / \mathrm{m})$} & \multicolumn{2}{|l|}{ SOM (\%) } \\
\hline & 2019 & 2020 & 2019 & 2020 & 2019 & 2020 \\
\hline A (NTF) & $6.47 \pm 0.38 a$ & $5.33 \pm 0.06 b$ & $0.78 \pm 0.07 a$ & $1.31 \pm 0.18 a b$ & $0.81 \pm 0.07 b$ & $1.03 \pm 0.05 \mathrm{ab}$ \\
\hline $\mathrm{B}(\mathrm{TF})$ & $6.34 \pm 0.08 a$ & $5.60 \pm 0.10 a$ & $0.39 \pm 0.00 c$ & $1.51 \pm 0.12 \mathrm{a}$ & $1.57 \pm 0.25 a$ & $0.82 \pm 0.05 b$ \\
\hline$C(T F)$ & $6.54 \pm 0.13 a$ & $5.70 \pm 0.10 \mathrm{a}$ & $0.41 \pm 0.03 b c$ & $0.98 \pm 0.13 b$ & $1.53 \pm 0.04 a$ & $0.83 \pm 0.25 b$ \\
\hline $\mathrm{D}(\mathrm{TF})$ & $6.40 \pm 0.24 a$ & $5.70 \pm 0.10 a$ & $0.47 \pm 0.04 b$ & $1.07 \pm 0.34 b$ & $1.53 \pm 0.04 a$ & $1.28 \pm 0.12 a$ \\
\hline
\end{tabular}

${ }^{1}$ Sites: $A=$ Mithapukur, $B=$ Badargonj $C=$ Gangachara, $D=$ Rangpur Sadar (NTF=Non-Tobacco field, $\mathrm{TF}=$ Tobacco field) 


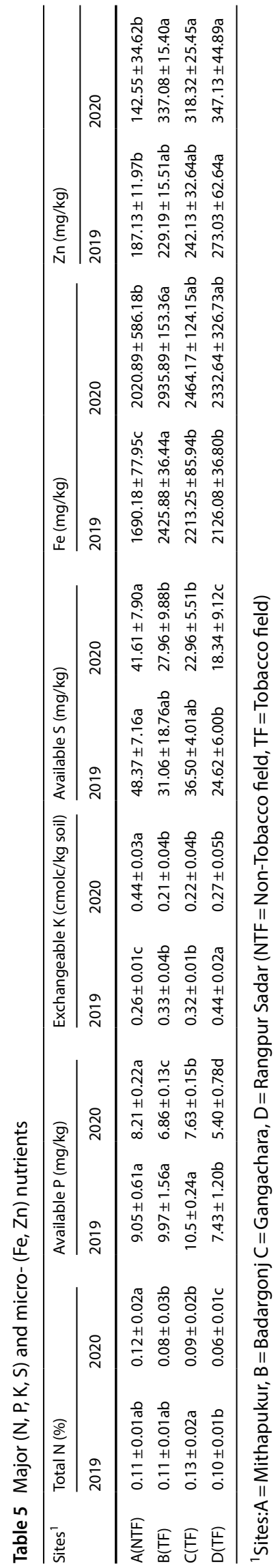

in all sites for the following year, and the data were statistically insignificant between tobacco and non-tobacco field except site B. Sahrawat [37] stated that, in soil solution, nutrient imbalance might be occurred due to the high concentration of iron because of an antagonistic relationship with some nutrients like $\mathrm{K}$ and $\mathrm{Zn}$. The concentration of $\mathrm{Zn}$ was declined in the non-tobacco field (187.13-142.55 mg/kg) but enhanced in all tobacco fields (248.12-334.24 mg/kg) along with significant differences with the non-tobacco field in 2020. According to Alloway [27], the regulatory limit of $Z n$ is less than $300 \mathrm{mg} / \mathrm{kg}$. In that sense, all tobacco fields exceeded the regulatory value in 2020 . $\mathrm{Zn}$ is an essential micronutrient that is necessary for proper plant growth. Still, an excess amount of $Z n$ negatively impacts soil microbial activities that inhibit plant growth. Alloway [27] reported that a high amount of $\mathrm{Zn}$ like $>500 \mathrm{mg} / \mathrm{kg}$ might hinder plant growth although crops can be grown in high $\mathrm{Zn}$ loading soils. Oloo [36] found that $\mathrm{Zn}$ concentration was higher in tobacco fields than virgin lands that support the study.

\subsection{Parameters related to exchangeable bases}

Results of successive year's cation exchange capacity (CEC), base saturation percentage (BSP), sodium adsorption ratio (SAR), exchangeable sodium percentage (ESP) are presented in Table 6. A yearly comparison of CEC results depicted that CEC of site $A$ was sharply decreased in 2020 (from 9.70 to $5.21 \mathrm{cmolc} / \mathrm{kg}$ ) whereas values of other sites were increased. In 2020, tobacco fields showed significantly lower CEC than all nontobacco fields. The opposite results were found for base saturation (BSP) that indicated significant incremental growth in non-tobacco fields. Only site A improved the BSP (40.86-52.98\% from 2019 to 2020) indicating the non-tobacco field might improve soil health. Results also stated that sodium adsorption ratio (SAR) and exchangeable sodium percentage (ESP) demonstrated a similar change and the values were increased in all four sites from 2019 to 2020. ESP was significantly higher in the non-tobacco field (3.51-9.92\%) than in tobacco fields in 2020 (Table 6). Hossain and Salam [38] reported in their study that soils with $70 \%$ or more BSP limit agronomic growth and soils are more likely to have structural stability problems with more than 6\% ESP. Though the BSP was less than the critical limit in this study, the ESP is more than $6 \%$ in two tobacco cultivated fields: site $B$ and site $C$, and non-tobacco field site $A$ which indicated the structural stability problems of soil-related to potential dispersion. 
Table 6 Parameters related to exchangeable bases

\begin{tabular}{|c|c|c|c|c|c|c|c|c|}
\hline \multirow[t]{2}{*}{ Sites $^{1}$} & \multicolumn{2}{|c|}{ CEC (cmolc/kg) } & \multicolumn{2}{|l|}{ BSP (\%) } & \multicolumn{2}{|l|}{ SAR } & \multicolumn{2}{|l|}{ ESP (\%) } \\
\hline & 2019 & 2020 & 2019 & 2020 & 2019 & 2020 & 2019 & 2020 \\
\hline A (NTF) & $9.70 \pm 1.96 a$ & $5.21 \pm 2.11 \mathrm{c}$ & $40.86 \pm 6.53 b$ & $52.98 \pm 9.78 a$ & $0.26 \pm 0.02 a$ & $0.54 \pm 0.12 \mathrm{a}$ & $3.51 \pm 0.47 b$ & $9.92 \pm 3.02 a$ \\
\hline$B(T F)$ & $8.14 \pm 0.33 b$ & $8.84 \pm 1.22 b$ & $51.21 \pm 1.90 a$ & $38.85 \pm 4.40 b$ & $0.26 \pm 0.01 a$ & $0.50 \pm 0.02 a$ & $4.26 \pm 0.25 a$ & $6.60 \pm 0.62 b$ \\
\hline$C(\mathrm{TF})$ & $9.45 \pm 2.49 a$ & $9.74 \pm 0.75 b$ & $42.54 \pm 6.52 b$ & $34.05 \pm 3.13 b$ & $0.27 \pm 0.02 a$ & $0.60 \pm 0.22 a$ & $3.74 \pm 0.54 b$ & $6.74 \pm 2.76 b$ \\
\hline $\mathrm{D}(\mathrm{TF})$ & $10.3 \pm 0.62 a$ & $11.33 \pm 1.75 a$ & $38.48 \pm 1.27 b$ & $30.67 \pm 1.06 b$ & $0.26 \pm 0.02 a$ & $0.43 \pm 0.06 a$ & $3.20 \pm 0.12 b$ & $4.44 \pm 2.17 c$ \\
\hline
\end{tabular}

${ }^{1}$ Sites: $A=$ Mithapukur, $B=$ Badargonj $C=$ Gangachara, $D=$ Rangpur Sadar (NTF = Non-Tobacco field, TF $=$ Tobacco field)

\subsection{Analysis of heavy metals}

Different values of successive year's heavy metals concentration are given in Table 7. Results illustrated that the concentration of $\mathrm{Mn}$ was the highest at site D $(428.79 \mathrm{mg} / \mathrm{kg})$ in 2019 . However, all sites' Mn concentration was reduced from 2019 to 2020 and showed significant differences between tobacco and nontobacco fields. According to Alloway [27] and WHO [28], $\mathrm{Mn}$ concentration of more than $80 \mathrm{mg} / \mathrm{kg}$ indicated a potential risk for soil. Thus all sites represented the $\mathrm{Mn}$ contamination in both years. Oloo [36] found that $\mathrm{Mn}$ concentration was higher in the tobacco field than that of the non-tobacco field that contradicts the research. Co concentration was found higher in the tobacco field as site D depicted the highest value in $2020(48.60 \mathrm{mg} /$ $\mathrm{kg}$ ). More importantly, tobacco fields loaded more Co rather than non-tobacco fields, whereas value nontobacco field decreased trend in successive year analysis (29.42-28.25 mg/kg). According to Alloway [27] and WHO [28], Co concentration ranged "between 1 and 40" $\mathrm{mg} / \mathrm{kg}$ indicated safe for soil. Thus, sites $C$ and $D$ (tobacco field) crossed the critical limit in 2020 that is a matter of concern. Oloo [36] found in his study that Co concentration was higher in the tobacco field than that of the nontobacco field that goes with the research. In terms of $\mathrm{Cr}$, the tobacco field loaded more concentration than nontobacco fields in successive year analysis where site $D$ expressed the highest value $(114.84 \mathrm{mg} / \mathrm{kg})$. A good sign was observed in the non-tobacco field where $\mathrm{Cr}$ value was diminished from 2019 to $2020(65.37-61.21 \mathrm{mg} / \mathrm{kg})$. According to Alloway [27] and WHO [28], Cr concentration ranged "between 1 and 100 " $\mathrm{mg} / \mathrm{kg}$ designated safe for soil. From Table 7, it was seen that sites $C$ and D (tobacco field) crossed the critical limit in 2020 that might be a potential cause for soil contamination. Oloo [36] found in his study that $\mathrm{Cr}$ concentration was higher in the tobacco field than that of the non-tobacco fields that sustained the research. In $\mathrm{Ni}$ analysis, significant loaded was observed in the tobacco field in successive year analysis (average 75.51-138.77 mg/kg). Oppositely, the value of site $A$ (non-tobacco field) was in a declining trend (32.19-26.58 mg/kg). A similar trend was also noticed in $\mathrm{Pb}$ analysis where site $\mathrm{D}$ was given the highest $\mathrm{Pb}$ loading data in $2020(824.95 \mathrm{mg} / \mathrm{kg})$. For both $\mathrm{Pb}$ and $\mathrm{Ni}$, data were statistically insignificant among tobacco fields and significant with the non-tobacco fields for both years' analysis. According to Alloway [27] and WHO [28] Ni concentration $<35 \mathrm{mg} / \mathrm{kg}$, Pd concentration $<85 \mathrm{mg} / \mathrm{kg}$ indicated safe for soil. Thus all sites of tobacco fields crossed the critical limit for both years that is a rising concern. Oloo [36] reported in his study that both $\mathrm{Ni}$ and $\mathrm{Pb}$ concentrations were higher in the tobacco field than that of the non-tobacco fields that support the study. This increased heavy metal contents in tobacco fields may be caused by the additional agrochemical inputs like insecticides and pesticides required by the tobacco plants which may contain the heavy metals in their composition as reported in the study of Kibwage et al. [8]. Some metals were found in the plants sprayed with pesticides in the study of Maobe et al. [39]. Šmejkalová et al. [40] found in their study that soil microbial populations were suppressed by the increased heavy metal contents due to loss of microbial enzymatic activities. The poor microbial community leads to poor soil health thus increasing environmental pressure due to heavy metal contamination.

\subsection{Pearson correlation coefficient micronutrients and heavy metals with soil pH and organic matter (SOM)}

Pearson's correlation coefficient study for the investigated for soil $\mathrm{pH}$ and soil organic matter (SOM) with micronutrient and heavy metal concentrations in soil are presented in Table 8. Study of 2019 depicted that significant positive correlation was shown between SOM-Co $\left(0.95^{*}\right)$, SOM-Ni $\left(0.96^{*}\right)$, Fe-Mo $\left(0.97^{*}\right), \mathrm{Zn}-\mathrm{Co}\left(0.95^{*}\right), \mathrm{Zn}-\mathrm{Ni}\left(0.96^{*}\right), \mathrm{Zn}-\mathrm{Pb}$ $\left(0.98^{*}\right)$, $\mathrm{Co}-\mathrm{Ni}\left(1.00^{* *}\right), \mathrm{Co}-\mathrm{Pb}\left(0.99^{* *}\right), \mathrm{Ni}-\mathrm{Pb}\left(0.99^{*}\right)$. In 


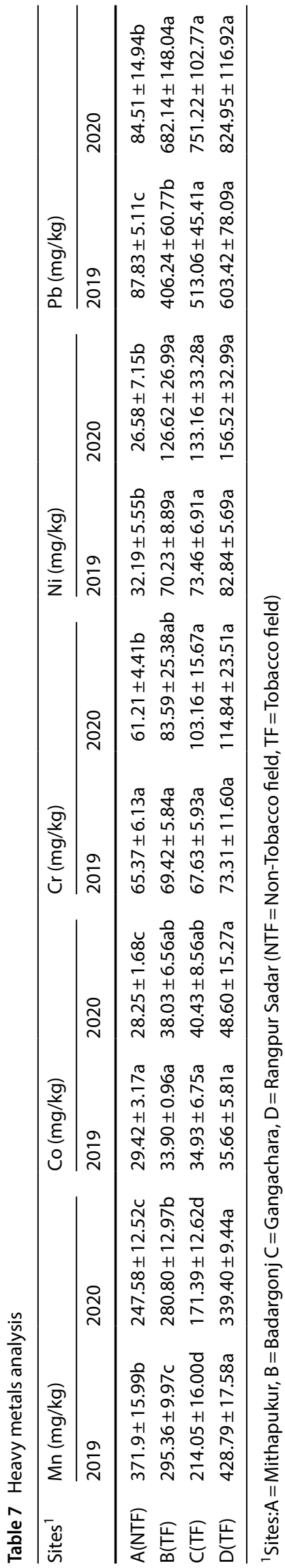

2020, significant positive correlation was seen between $\mathrm{pH}-\mathrm{Ni}\left(0.98^{*}\right), \mathrm{pH}-\mathrm{Pb}\left(0.99^{*}\right), \mathrm{Fe}-\mathrm{Mo}\left(1.0^{* *}\right), \mathrm{Zn}-\mathrm{Ni}\left(0.98^{*}\right)$, $\mathrm{Zn}-\mathrm{Pb}\left(0.99^{*}\right), \mathrm{Co}-\mathrm{Cr}\left(0.97^{*}\right), \mathrm{Ni}-\mathrm{Pb}\left(1.00^{* *}\right)$. Other's correlations were found to be nonsignificant which means the concentration of one element may not influence other elements concentrations in the studied area.

Overall, correlation study of successive years recapitulated that in most of the cases; heavy metals were positively correlated with each other. So, heavy metals loading should be controlled otherwise increment of any heavy metal might be caused for other heavy metals load in the studied soil. Similar findings were observed by Khaledian et al. 2016 [41].

\subsection{Heavy metal pollution and ecological risk assessment}

The values of soil pollution indices (SPI) in the successive year are given in Table 9. The SPI value of $M n$ in the non-tobacco field was reduced from 4.65 to 3.09 in the successive year. The same scenario was also observed in the tobacco field. The highest SPI value of $M n$ was seen at site D in 2019 (5.36) which indicated high pollution. However, except site D in 2019, all studied soils were moderately $\mathrm{Mn}$ polluted, referred to by Zang et al. [29]. For Co, the SPI value in the non-tobacco field was minimized from 0.74 to 0.71 in the consecutive year. But the opposite scenario was noticed in all tobacco fields. Co's highest SPI value was found at site D in 2020 (1.21) which indicated slight pollution. However, except site $D$ in 2020, all studied soils were Co unpolluted as referred by Zang et al. [29]. In addition, Cr's SPI value in the nontobacco field was diminished from 0.65 to 0.61 in the following year. But the opposite scenario was identified in all tobacco fields. The highest SPI value of $\mathrm{Cr}$ was observed at site D in 2020 (1.15) which indicated slight pollution. However, except for sites $C$ and D in 2020, all studied soils were $\mathrm{Cr}$ unpolluted as referred by Zang et al. [29]. Additionally, Ni's SPI value in the non-tobacco field was lessened from 0.92 to 0.76 in the subsequent year. But the reverse scenario was reported in all tobacco fields. The highest SPI value of Ni was detected at site D in 2020 (4.47) which indicated moderate pollution. However, except site $\mathrm{A}$, all studied soils were moderately $\mathrm{Ni}$ polluted as referred by Zang et al. [29]. Moreover, the SPI value of $\mathrm{Pb}$ in the non-tobacco field was reduced from 1.03 to 0.99 in the succeeding year. But the opposite scenario was noted in all tobacco fields. The highest SPI value of $\mathrm{Pb}$ was detected at site $\mathrm{D}$ in 2020 (9.71), which indicated high pollution. However, sites A and B in 2019 expressed slight pollution and nonpolluting status in 2020 site A. All other studied soils were highly Pb polluted as referred by Zang et al. [29]. An overall analysis 
Table 8 Pearson correlation coefficient of micronutrients and heavy metals with soil $\mathrm{pH}$ and organic matter (SOM)

\begin{tabular}{|c|c|c|c|c|c|c|c|c|c|c|}
\hline \multicolumn{11}{|c|}{ Soil Properties in 2019} \\
\hline & $\mathrm{pH}$ & SOM & $\mathrm{Fe}$ & $\mathrm{Mn}$ & Mo & $\mathrm{Zn}$ & Co & $\mathrm{Cr}$ & $\mathrm{Ni}$ & $\mathrm{Pb}$ \\
\hline \multicolumn{11}{|c|}{ Soil Properties in 2019} \\
\hline $\mathrm{pH}$ & 1 & & & & & & & & & \\
\hline SOM & -0.29 & 1 & & & & & & & & \\
\hline $\mathrm{Fe}$ & -0.43 & 0.93 & 1 & & & & & & & \\
\hline $\mathrm{Mn}$ & -0.45 & -0.32 & -0.45 & 1 & & & & & & \\
\hline Mo & -0.24 & 0.88 & $0.97^{*}$ & -0.65 & 1 & & & & & \\
\hline $\mathrm{Zn}$ & -0.18 & 0.84 & 0.60 & 0.11 & 0.48 & 1 & & & & \\
\hline Co & -0.15 & $0.95^{*}$ & 0.78 & -0.18 & 0.72 & $0.95 *$ & 1 & & & \\
\hline $\mathrm{Cr}$ & -0.53 & 0.70 & 0.51 & 0.44 & 0.32 & 0.91 & 0.79 & 1 & & \\
\hline $\mathrm{Ni}$ & -0.24 & $0.96^{*}$ & 0.80 & -0.12 & 0.72 & $0.96^{*}$ & $1.00^{* *}$ & 0.83 & 1 & \\
\hline $\mathrm{Pb}$ & -0.12 & 0.92 & 0.71 & -0.10 & 0.64 & $0.98^{*}$ & $0.99^{* *}$ & 0.82 & $0.99 *$ & 1 \\
\hline \multicolumn{11}{|c|}{ Soil Properties in 2020} \\
\hline $\mathrm{pH}$ & 1 & & & & & & & & & \\
\hline SOM & 0.02 & 1 & & & & & & & & \\
\hline $\mathrm{Fe}$ & 0.53 & -0.55 & 1 & & & & & & & \\
\hline $\mathrm{Mn}$ & 0.07 & 0.73 & 0.06 & 1 & & & & & & \\
\hline Mo & 0.60 & -0.52 & $1.00^{* * *}$ & 0.06 & 1 & & & & & \\
\hline $\mathrm{Zn}$ & 0.95 & -0.03 & 0.72 & 0.24 & 0.78 & 1 & & & & \\
\hline Co & 0.91 & 0.42 & 0.32 & 0.43 & 0.39 & 0.88 & 1 & & & \\
\hline $\mathrm{Cr}$ & 0.94 & 0.33 & 0.24 & 0.20 & 0.33 & 0.84 & $0.97^{*}$ & 1 & & \\
\hline $\mathrm{Ni}$ & $0.98^{*}$ & 0.10 & 0.59 & 0.25 & 0.66 & $0.98^{*}$ & 0.94 & 0.93 & 1 & \\
\hline $\mathrm{Pb}$ & $0.99 *$ & 0.03 & 0.61 & 0.18 & 0.68 & $0.99 *$ & 0.92 & 0.92 & $1.00^{* *}$ & 1 \\
\hline
\end{tabular}

${ }^{*}$ Correlation is significant at the 0.05 level (2-tailed)

${ }^{* *}$ Correlation is significant at the 0.01 level (2-tailed) of SPI presented that all heavy metal pollution status was decreased in the non-tobacco field from 2019 to 2020 and the reverse has happened in all tobacco fields except $\mathrm{Mn}$. In 2019, the value of each heavy metal was decreasing order $\mathrm{Pb}>\mathrm{Mn}>\mathrm{Ni}>\mathrm{Co}>\mathrm{Cr}$, whereas in 2020, it was changed to $\mathrm{Pb}>\mathrm{Ni}>\mathrm{Mn}>\mathrm{Co}>\mathrm{Cr}$.

The values of ecological risk (ER) for individual heavy metals in the successive year are also given in Table 9. Among the heavy metal, Mn values of side D (53.60 and 42.43 successively) illustrated the moderate risk of pollution which was a tobacco field. Though the Mn value of site $A$ (46.49) in 2019 was presented at a moderate risk of pollution, the ER of $\mathrm{Mn}$ (30.95) in 2020 stated the low risk of pollution. However, all other metals were symbolized a low risk of pollution as referred by Hakanson [30]. The most vulnerable condition was seen in $\mathrm{Pb} E R$ values where all tobacco fields in 2020 denoted the moderate risk of pollution ( $>40$ ) although the values in 2019 were at low risk $(<40)$. For other metals, ER values of tobacco fields were higher than the non-tobacco field though these were signified in low risk of pollution.

According to Table 10, the ecological risk index (RI) of tobacco fields was higher than the non-tobacco fields for both years. In 2019, the RI value of site A (non-tobacco field) was 62.16 that was diminished to 45.23 . This is a good sign of soil quality improvement for the non-tobacco field. The RI value was the highest in site $D$ (tobacco field) which was 109.22 in 2019, increased to 126.16 in 2020. Similar situations were also noticed for sites $B$ and $C$ which were also tobacco fields. According to Xia et al. [32], the RI value of more than 112.5 is characterized by moderate ecological risk. In that sense, site D (tobacco field) in 2020 (126.16) placed the moderate ecological risk of pollution along with all tobacco fields were got higher RI value in 2020 than that of 2019 which is a matter of great concern. These should be taken as top consideration as soon as possible. Otherwise, these tobacco fields can immerge in moderate to higher ecological risk soon. Good improvement was observed in the non-tobacco field (site A) where RI value was got lower 
Table 9 Soil pollution and ecological risk status of sampling sites in the successive year

\begin{tabular}{|c|c|c|c|c|c|c|c|c|c|}
\hline Sites $^{1}$ & Metals & $\begin{array}{l}\text { SPI value } \\
\text { in } 2019\end{array}$ & $\begin{array}{l}\text { Soil pollution } \\
\text { status in } 2019\end{array}$ & $\begin{array}{l}\text { SPI value } \\
\text { in } 2020\end{array}$ & $\begin{array}{l}\text { Soil pollution } \\
\text { status in } 2020\end{array}$ & ER value in 2019 & $\begin{array}{l}\text { Ecological risk } \\
\text { status in } 2019\end{array}$ & ER value in 2020 & $\begin{array}{l}\text { Ecological risk } \\
\text { status in } 2020\end{array}$ \\
\hline A (NTF) & $\mathrm{Mn}$ & 4.65 & Moderate & 3.09 & Moderate & 46.49 & Moderate & 30.95 & Low \\
\hline $\mathrm{B}(\mathrm{TF})$ & & 3.69 & Moderate & 3.51 & Moderate & 36.92 & Low & 35.10 & Low \\
\hline$C(T F)$ & & 2.68 & Mild & 2.14 & Mild & 26.76 & Low & 21.42 & Low \\
\hline $\mathrm{D}(\mathrm{TF})$ & & 5.36 & High & 4.24 & Moderate & 53.60 & Moderate & 42.43 & Moderate \\
\hline A (NTF) & Co & 0.74 & Low & 0.71 & Unpolluted & 3.68 & Low & 3.53 & Low \\
\hline$B(T F)$ & & 0.85 & Low & 0.95 & Unpolluted & 4.24 & Low & 4.75 & Low \\
\hline$C(\mathrm{TF})$ & & 0.87 & Low & 1.01 & Slight & 4.37 & Low & 5.05 & Low \\
\hline $\mathrm{D}(\mathrm{TF})$ & & 0.89 & Low & 1.21 & Slight & 4.46 & Low & 6.07 & Low \\
\hline A (NTF) & $\mathrm{Cr}$ & 0.65 & Low & 0.61 & Unpolluted & 1.31 & Low & 1.22 & Low \\
\hline $\mathrm{B}(\mathrm{TF})$ & & 0.69 & Low & 0.84 & Unpolluted & 1.39 & Low & 1.67 & Low \\
\hline$C(\mathrm{TF})$ & & 0.68 & Low & 1.03 & Slight & 1.35 & Low & 2.06 & Low \\
\hline $\mathrm{D}(\mathrm{TF})$ & & 0.73 & Low & 1.15 & Slight & 1.47 & Low & 2.30 & Low \\
\hline A (NTF) & $\mathrm{Ni}$ & 0.92 & Low & 0.76 & Unpolluted & 5.52 & Low & 4.56 & Low \\
\hline B (TF) & & 2.01 & Mild & 3.62 & Moderate & 12.04 & Low & 21.71 & Low \\
\hline$C(\mathrm{TF})$ & & 2.10 & Mild & 3.80 & Moderate & 12.59 & Low & 22.83 & Low \\
\hline $\mathrm{D}(\mathrm{TF})$ & & 2.37 & Mild & 4.47 & Moderate & 14.20 & Low & 26.83 & Low \\
\hline A (NTF) & $\mathrm{Pb}$ & 1.03 & Slight & 0.99 & Unpolluted & 5.17 & Low & 4.97 & Low \\
\hline $\mathrm{B}(\mathrm{TF})$ & & 4.78 & Moderate & 8.03 & High & 23.90 & Low & 40.13 & Moderate \\
\hline$C(\mathrm{TF})$ & & 6.04 & High & 8.84 & High & 30.18 & Low & 44.19 & Moderate \\
\hline $\mathrm{D}(\mathrm{TF})$ & & 7.10 & High & 9.71 & High & 35.50 & Low & 48.53 & Moderate \\
\hline
\end{tabular}

${ }^{1}$ Sites:A = Mithapukur, $\mathrm{B}=$ Badargonj $\mathrm{C}=$ Gangachara, $\mathrm{D}=$ Rangpur Sadar (NTF = Non-Tobacco field, TF $=$ Tobacco field)

in 2020 (45.23) than that in 2019 (62.16). The overall progression of $\mathrm{SPI}, \mathrm{ER}$, and $\mathrm{RI}$ is shown in Figs. 2, 3. The ER and RI is the potential indicator for the assessing ecological risk of soil heavy metals [42]. The overall results predicted a moderate risk of soil heavy metal pollution in tobacco fields especially $\mathrm{Pb}$ and $\mathrm{Mn}$. $\mathrm{Pb}$ also represented a high pollution index (PI). This is potentially harmful because $\mathrm{Pb}$ is easily absorbed by crops and damages human health when ingested [43]. So,

Table 10 Risk status of sampling sites in the successive year

\begin{tabular}{lllrl}
\hline Sites $^{1}$ & $\begin{array}{l}\text { Risk index } \\
\text { value in } \\
2019\end{array}$ & $\begin{array}{l}\text { Risk } \\
\text { status in } \\
2020\end{array}$ & $\begin{array}{l}\text { Risk index } \\
\text { value in } \\
2020\end{array}$ & Risk status in 2019 \\
\hline A (NTF) & 62.16 & Low & 45.23 & Low \\
B (TF) & 78.48 & Low & 103.36 & Low \\
C (TF) & 75.25 & Low & 95.56 & Low \\
D (TF) & 109.22 & Low & 126.16 & Moderate \\
\hline
\end{tabular}

${ }^{1}$ Sites: $A=$ Mithapukur, $B=$ Badargonj $C=$ Gangachara, $D=$ Rangpur Sadar (NTF=Non-Tobacco field, TF=Tobacco field)
$\mathrm{Pb}$ pollution should be controlled and tobacco farming is needed to discourage farmers due to higher RI value.

\section{Conclusion}

Tobacco cultivation is a common practice in the study area that is increasing day by day and the fertile lands of this area are affected by the negative impact of frequent tobacco cultivation. The physicochemical study revealed that soil porosity was affected by tobacco cultivation and organic matter contents were reduced in the tobacco cultivated soils that are hazardous for soil health. Tobacco is a nutrient hunger plant which in turn caused nutrient depletion of the cultivated land. This study found the depletion of the major soil nutrients like N, P, K, S in tobacco cultivated lands compared to the non-tobacco cultivated fields. The major alarming part is that tobacco cultivation caused heavy metal ( $\mathrm{Mn}, \mathrm{Mo}, \mathrm{Co}, \mathrm{Cr}, \mathrm{Ni}, \mathrm{Pb}$ ) accumulation in the study area due to its additional fertilizer, pesticide, and insecticide requirements. Overall correlation studies 


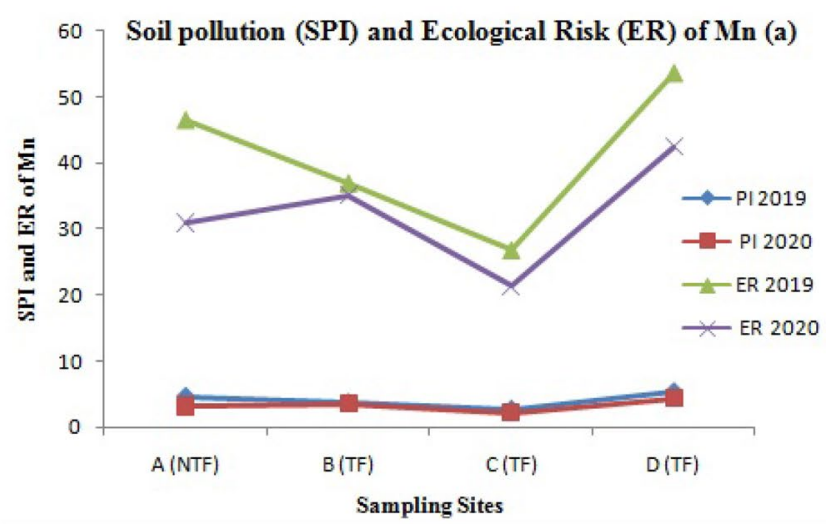

Soil pollution (SPI) and Ecological Risk (ER) of Co (b)
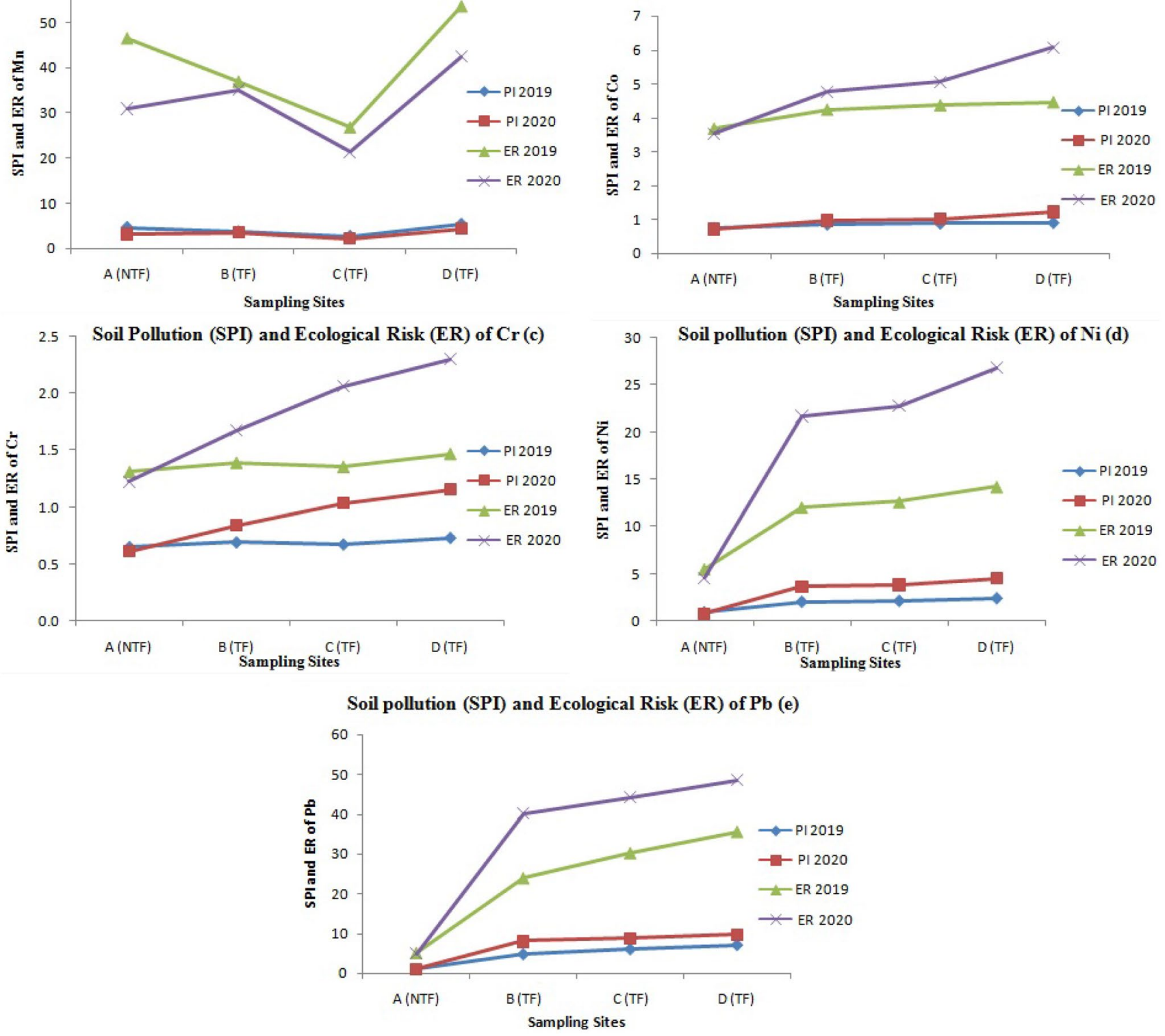

Fig. 2 Pollution index and ecological risk index of $\mathrm{Mn}(\mathrm{a}), \mathrm{Co}(\mathrm{b}), \mathrm{Cr}(\mathrm{c}), \mathrm{Ni}(\mathrm{d}), \mathrm{Pb}$ (e) in the tobacco and non-tobacco fields

also stated that there was a significant positive relationship between heavy metals and soil properties. $\mathrm{Mn}$ and $\mathrm{Pb}$ concentration were elaborated the moderate risk of heavy metal pollution. The RI value illustrated that the tobacco field in Rangpur Sadar is at moderate risk of pollution as well as all other tobacco fields are at the potential risk of pollution. Therefore, tobacco cultivation leads to soil fertility depletion and heavy metal contamination in the study area. However, tobacco's alternative profitable crops are to be suggested in this area to prevent soil quality degradation caused by tobacco cultivation.

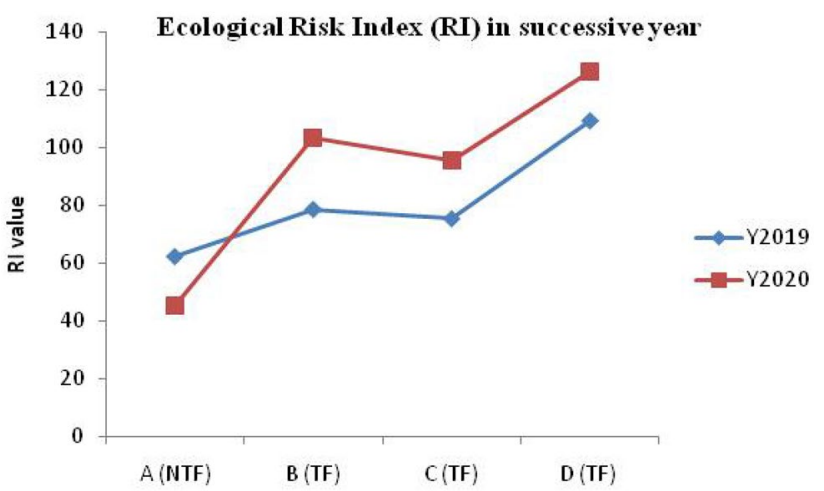

Fig. 3 Ecological risk index assessment of the tobacco and nontobacco fields in the successive years 
Acknowledgements The authors thank Soil, Water and Environment Discipline for providing the laboratory facility. Also, show gratitude to all stakeholders in the experimental area for correspondence.

Authors' Contribution Md. Tareq Bin Salam initiated and designed the research work. S. M. Shahriar Zaman, S. M. Tanzim Hossen and Md. Asaduzzaman Nur helped in collecting data from the field. Shahriar also wrote the manuscript and Tareq corrected as well as improved the manuscript. Tanzim and Asaduzzaman helped Shahriar to compile the final result. Finally, all authors read and approved the final manuscript.

Funding The research was funded by Khulna University Research Cell, Khulna University, Bangladesh (Grant no. KU/Rcell-04/2000-74).

\section{Compliance with ethical standards}

Confllict of interests The authors declare that they have no conflict of interest.

Open Access This article is licensed under a Creative Commons Attribution 4.0 International License, which permits use, sharing, adaptation, distribution and reproduction in any medium or format, as long as you give appropriate credit to the original author(s) and the source, provide a link to the Creative Commons licence, and indicate if changes were made. The images or other third party material in this article are included in the article's Creative Commons licence, unless indicated otherwise in a credit line to the material. If material is not included in the article's Creative Commons licence and your intended use is not permitted by statutory regulation or exceeds the permitted use, you will need to obtain permission directly from the copyright holder. To view a copy of this licence, visit http://creativecommons .org/licenses/by/4.0/.

\section{References}

1. BUMC (1999) History of tobacco. Community outreach health information system, Boston University Medical Center (BUMC), Boston, MA 02118, USA

2. Sarkar H (2001) Tobacco agricultural research in Bangladesh in the 20th century. Bangladesh Agricultural Research Council, Dhaka, Bangladesh

3. BARC (2012) Fertilizer recommendation guide. Bangladesh agricultural research council (BARC), Farmgate, Dhaka, Bangladesh

4. Barkat A, Chowdhury AU, Nargis N, Rahman M, Khan MS, Kumar PKA, Bashir S, Chaloupka FJ (2012) The economics of tobacco and tobacco taxation in Bangladesh. International Union against Tuberculosis and Lung Disease, Paris, France

5. Akhter F (2011) Tobacco cultivation and its impact on food production in Bangladesh. Unnayan Bikalper Nitinirdharoni Gobeshona (UBINIG), Dhaka, Bangladesh

6. Yanda PZ (2010) Impact of small scale tobacco growing on the spatial and temporal distribution of Miombo woodlands in Western Tanzania. J Ecol Nat Environ 2:10-16

7. Geist JH (1999) Soil mining and societal responses: the case of tobacco in eastern miombo highlands. In: Lohnert B, Geist H (eds) Coping with changing environments. Ashgate publishing Ltd, Aldershot, pp 119-148

8. Kibwage JK, Netondo GW, Odondo AJ, Oindo BO, Momanyi GM, Jinhe F (2008) Growth performance of bamboo in tobacco-growing regions in South Nyanza Kenya. Afr J Agric Res 3(10):716-724

9. Proshad R, Zhang D, Uddin M, Yi W (2020) Presence of cadmium and lead in tobacco and soil with ecological and human health risk in Sichuan province, China. Environ Sci Pollut Res 27:18355-18370. https://doi.org/10.1007/s11356-020-08160 $-1$

10. Shun-hong H, Bing P, Zhi-hui Y, Li-yuan C, Li-cheng Z (2009) Chromium accumulation, microorganism population and enzyme activities in soils around chromium-containing slag heap of steel alloy factory. Trans Nonferrous Metals Soc China 19:241-248. https://doi.org/10.1016/S1003-6326(08)60259-9

11. BBS (2019) Yearbook of agricultural statistics-2018. Bangladesh Bureau of Statistics (BBS), statistics and informatics division, Ministry of planning, Government of the People's Republic of Bangladesh, Dhaka, Bangladesh

12. Salam MTB, Zaman SMS, Nuralom M, Hossain M (2019) Strategic groundwater management planning for rice field in Rangpur division, Bangladesh. Curr World Environ 14 (2) 320 325. https ://doi.org/10.12944/CWE.14.2.16

13. USDA (1951) Soil survey manual by soil survey staff. Bureau of plant industry, United States Department of Agriculture (USDA). Soil and agriculture Engineering, Handbook No.18: 205

14. Blake GR, Hartge KH (1986) Bulk density. In: Klute A (ed) Methods of soil analysis, Part 1: physical and mineralogical methods, 2nd edn. Agronomy Monograph 9, American Society of Agronomy-Soil Science Society of America, Madison, Wisconsin, pp 363-382

15. Danielson RE, Sutherland PL (1986) Porosity. In: Klute A (ed) Methods of soil analysis, Part 1: physical and mineralogical methods, 2nd edn. American Society of Agronomy-Soil Science Society of America, Madison, Wisconsin, pp 443-461

16. ISO (2002) Soil quality-determination of ph.international organization for standardization (ISO) 10, 390

17. Walkley A, Black IA (1934) An examination of the digestion method for determining soil organic matter and a proposed modification of the chromic acid titration method. Soil Sci 37:29-38. https://doi.org/10.1097/00010694-193401000-00003

18. Nelson DW, Sommers LE (1996) Total carbon, organic carbon, and organic matter. In: Sparks DL et al (eds) Methods of soil analysis, Part 3: chemical methods. SSSA Book Series, Madison, pp 961-1010

19. Bremner JM, Mulvaney CS (1982) Nitrogen-Total. In: Page AL, Miller RH, Keeney DR (eds) Methods of soil analysis, Part 2: chemical and microbiological properties, 2 nd edn. American Society of Agronomy-Soil Science Society of America, Madison, Wisconsin, pp 595-624

20. Frank KD, Beegle, Denning J (1998) Phosphorus. In: Brown JR (ed) Recommended chemical soil test procedures for the northcentral region, North Central Regional Research Publication No. 221 (Revised), Missouri Agricultural Experiment Station SB 1001, Columbia, USA

21. Page AL, Miller RH, Keeney DR (1982) Methods of soil analysis, Part 2: chemical and microbiological properties, 2nd edn. American Society of Agronomy-Soil Science Society of America, Madison, Wisconsin, USA

22. Olorunfemi IE, Fasinmirin JT, Ojo AS (2016) Modeling of cation exchange capacity and soil water holding capacity from basic soil properties. Eurasian J Soil Sci 5 (4) 266-274. https://doi. org/10.18393/ejss.2016.4.266-274

23. Senjobi BA, Ogunkunle OA (2010) Effect of land use on soil degradation and soil productivity decline on Alfisols and Ultisols in Ogun State in Southern Western Nigeria. Agric Conspec Sci 75(1):9-19 
24. Chapman HD (1965) Cation exchange capacity. In: Black CA (ed) Methods of soil analysis. American Society of Agronomy, Madison, pp 891-901

25. Piper CS (1966) Mineral analysis by wet digestion with sulfuric acid. Soil and Plant Analysis. Hans Publishers, Bombay, India, pp 272-274

26. Aydin I, Yuksela U, Guzelb R, Ziyadanogullaria B, Aydina F (2010) Determination of trace elements in Turkish Wines by ICP-OES and HG-ICP-OES. At Spectrosc 31(1):67-71

27. Alloway BJ (2013) Heavy metals in soils: trace metals and metalloids in soils and their bioavailability, 3rd edn. Springer, Dordrecht

28. WHO (1996) Permissible limits of heavy metals in soil and plants. World Health Organization(WHO), Geneva, Switzerland

29. Zang F, Wang S, Nan Z, Ma J, Zhang Q, Chen Y, Li Y (2017) Accumulation, Spatio-temporal distribution, and risk assessment of heavy metals in the soil-corn system around a polymetallic mining area from the Loess Plateau, northwest China. Geoderma 305:188-196. https://doi.org/10.1016/j.geoderma.2017.06.008

30. Hakanson $L$ (1980) An ecological risk index for aquatic pollutioncontrol-a sedimentological approach. Water Res 14:975-1001. https://doi.org/10.1016/0043-1354(80)90143-8

31. Wang Y, Yang L, Kong L, Liu E, Wang L, Zhu J (2015) Spatial distribution, ecological risk assessment and source identification for heavy metals in surface sediments from Dongping Lake, Shandong, East China. CATENA 125:200-205. https://doi. org/10.1016/j.catena.2014.10.023

32. Xia W, Wang R, Zhu B, Rudstam GL, Liu Y, Xu Y, Xin W, Chen $Y$ (2020) Heavy metal gradients from rural to urban lakes in central China. Ecol Process 9:47. https://doi.org/10.1186/s13717-02000251-8

33. Weil RR, Brady NC (2017) The nature and properties of soils, 15th edn. Pearson, Columbus

34. Moula MS, Hossain MS, Farazi MM, Ali MH, Mamun MAA (2018) Effects of consecutive two years tobacco cultivation on soil fertility status at Bheramaraupazilla in Kushtia district. J Rice Res 6:190. https://doi.org/10.4172/2375-4338.1000190
35. Kutub JR, Falgunee N (2015) Environmental degradation due to tobacco cultivation in Bangladesh: a case study of Doulathpur. Kushtia Malays J Soc Space 11(7):1-8

36. Oloo KP (2016) Tobacco cultivation effects on soil fertility and heavy metals concentration on smallholder farms in Western Kenya. J Agric Sci Food Tech 2(5):75-79

37. Sahrawat KL (2004) Iron toxicity in wetland rice and the role of other nutrients. J Plant Nutr 27:1471-1504. https://doi. org/10.1081/PLN-200025869

38. Hossain M, Salam MTB (2019) Changes in Soil Physico-chemical properties and fertility status of long-term cultivated soils in southwestern Bangladesh. Malaysian J Soil Sci 23:31-41. https ://doi.org/10.26480/bda.01.2019.03.06

39. Maobe MA, Gatebe E, Gitu L, Rotich H (2012) Profile of heavy metals in selected medicinal plants used for the treatment of diabetes, malaria and pneumonia in Kisii region. Southwest Kenya Global J Pharmacol 6(3):245-251

40. Šmejkalová M, Mikanová O, Borůvka L (2003) Effects of heavy metal concentrations on biological activity of soil micro-organisms. Plant Soil Environ. 49: 321-326. https://doi.org/10.17221 /4131-PSE

41. Khaledian Y, Pereira P, Brevik EC, Pundyte N, Paliulis D (2016) The influence of organic carbon and $\mathrm{pH}$ on heavy metals, potassium, and magnesium levels in Lithuanian podzols. Land Degrad Develop 28(1):345-354. https://doi.org/10.1002/ldr.2638

42. Jiang X, Xiong Z, Liu H, Liu G, Liu W (2017) Distribution, source identification, and ecological risk assessment of heavy metals in wetland soils of a river-reservoir system. Environ Sci Pollut Res 24(1):436-444. https://doi.org/10.1007/s11356-016-7775-x

43. Hu B, Jia X, Hu J, Xu D, Xia F, Li Y (2017) Assessment of heavy metal pollution and health risks in the soil-plant-human system in the Yangtze river delta, China. Int J Environ Res Pub Health 14(9):1042. https://doi.org/10.3390/ijerph14091042

Publisher's Note Springer Nature remains neutral with regard to jurisdictional claims in published maps and institutional affiliations. 